\title{
Treatment of Operative Pain in Visceral Cancer Surgery at CHU Gabriel Toure
}

\author{
Dembélé Bakary Tientigui, Traoré Alhassane, Togo Adégné, Kante Lassana, Diakité Ibrahim, \\ Konate Madiassa, Traore Amadou, Diakité Boubacar, Bah Amadou, Sidibé Yoro, Koné Tany, \\ Diop Thiorno Madani, Django Djibo, Diallo Gangaly
}

Department of General Surgery, CHU Gabriel-Touré, Bamako, Mali

Email: btdembele@gmail.com

How to cite this paper: Tientigui, D.B., Alhassane, T., Adégné, T., Lassana, K., Ibrahim, D., Madiassa, K., Amadou, T., Boubacar, D., Amadou, B., Yoro, S., Tany, K., Madani, D.T., Djibo, D. and Gangaly, D. (2017) Treatment of Operative Pain in Visceral Cancer Surgery at CHU Gabriel Toure. Surgical Science, 8, 47-51.

http://dx.doi.org/10.4236/ss.2017.81006

Received: December 15, 2016

Accepted: January 13, 2017

Published: January 16, 2017

Copyright $\odot 2017$ by authors and Scientific Research Publishing Inc. This work is licensed under the Creative Commons Attribution International License (CC BY 4.0).

http://creativecommons.org/licenses/by/4.0/ (c) (i) Open Access

\begin{abstract}
The objectives were to determine the frequency of pain in cancer patients and its intensity in cancer pathologies and to evaluate the evolution of pain intensity after analgesic treatment; the effectiveness of its management study involved 121 cases of operated gastrointestinal cancers, which accounted for $85.82 \%$ (141) of operated cancers and $16.78 \%$ (721) of all operated patients; the average age of our patients was 49.93 years with extremes 17 and 78 years. Standard deviation: 15.75 ; with a sex ratio of 1.46 . The majority of our patients had WHO III (54/121) or $44.6 \%$; $46.3 \%(56 / 121)$ of patients were in stage IV of the TNM classification. The main digestive cancers were cancer of the esophagus 4 cases (3.3\%); of the stomach 61 cases $(50.4 \%)$; of the pancreas 7 cases (5.8\%); of the liver 4 cases (3.3\%); gall bladder 2 cases (1.6\%); colon 33 cases (27.3\%); rectum 6 cases $(4.9 \%)$ and hail 4 cases (3.3\%). The average pain intensities were 3 to 6 hour; 2 to 24 hour; 1.6 to 48 hour; and 1.2 to 72 hour. The majority of our patients had a treatment protocol involving nefopam, and paracetamol was $58 \%$. The pain was exacerbated especially during exercise. Vomiting and vein burning were the main side effects encountered.
\end{abstract}

\section{Keywords}

Pain, Cancer, Bamako Surgery, Mali

\section{Introduction}

Pain is the most frequently observed symptom in oncology, thus constituting for the clinician one of the main axes of its management. The incidence of pain varies depending on the type and stage of cancer. It is present in 30\% to $45 \%$ of patients at the time of diagnosis or early stage of the disease and in $60 \%$ to $90 \%$ of patients with advanced disease [1]. 
Globally, the number of cancer patients is increasing [2]. More than half of new cases occur in developing countries. In most cases, the disease is diagnosed late [2].

More than $80 \%$ of patients with advanced metastatic disease suffer from pain mainly due to direct tumor infiltration. The pain compromises the quality of life considerably and is an important indicator in tumor progression. Cancer pain can be acute or chronic and should be treated accordingly [2]

Various ways are available to treat pain. Analgesics, neurosurgery, as well as psychological and behavioral approaches, must be adapted to the individual needs of the patient [3]. Correct management of pain not only improves the comfort of the patient but also significantly reduces the response to surgical stress, which in turn reduces the rate of complications (infection, anastomotic fistula), morbidity (pneumonia, Thrombosis, embolism), time to re-convalescence and even mortality [4].

\section{Patients and Methods}

This is a 12-month analytical prospective study from January 1 to December 31, 2015, carried out in the Department of General Surgery of the CHU Gabriel Touré ( $3^{\text {rd }}$ reference), including all patients operated in the general surgery department for cancer, Assessment of the intensity of pain, the application of the management protocol and with informed and free consent (accepted by ethics committee).

The systematic administration of analgesic as soon as the surgical wound closes and not on demand (paracetamol injectable 30).

Assessment of the intensity of pain in relation to certain factors including: Pathology, procedure, rest and movement. Pain intensity and relief are measured at times $\mathrm{T}=0$ (initial time), $\mathrm{T}=6 \mathrm{~h}, \mathrm{~T}=24 \mathrm{~h}, \mathrm{~T}=48 \mathrm{H}, \mathrm{T}=72 \mathrm{H}$.

The scales used for this study were EVS (Echelle Verbale Simple), and EVA (Echelle VisuelleAnalogique).

As protocol: Analgesic treatment by the administration of various molecules (paracetamol injectable, Nefopam injectable, Morphine injectable).

Injectable paracetamol (administered at $15 \mathrm{mg} / \mathrm{kg}$ body weight), the vial (administered intravenously as an infusion for 15 minutes).

The first bottle (administration as soon as the wound was closed), the dose was renewed every 8 hours.

The injectable nefopam was $20 \mathrm{mg}$ postoperatively; to maintain analgesia:

Continuous infusion of 4 to 6 ampoules in 24-hour isotonic serum or discontinuous slow infusion, one ampoule over 30 to 60 minutes; Renewable every 4 hours, without exceeding the dose of $120 \mathrm{mg}$ ( 6 ampoules per 24 hours).

Tramadol Hydrochloride $100 \mathrm{mg}$ (intravenous slow injection every 8 hours).

Injectable Morphine: 5 to $10 \mathrm{mg} / \mathrm{kg}$ (subcutaneously every 4 to 6 hours).

The data was entered and analyzed on SPSS and EpiInfo ${ }^{\mathrm{TM}}$ software version $6.0 \mathrm{Fr}$. The comparison test used was Chi2 (statistically significant difference if $\mathrm{p} \leq 0.05$ ).

\section{Results}

Our study involved 121 cases of operated gastrointestinal cancers, which accounted for $85.82 \%$ (141) of operated cancers and $16.78 \%$ (721) of all operated patients; the average 
age of our patients was 49.93 years with extremes 17 and 78 years. Standard deviation: 15.75; with a sex ratio of 1.46 .

The majority of our patients had WHO III (54/121) or 44.6\%; and $46.3 \%(56 / 121)$ of patients were in stage IV of the TNM classification.

The main digestive cancers are summarized in Table 1.

Adenocarcinoma was the most found histological type with 95\%. Among the adenocarcinomas of the colon there was a cancer with independent cells in "ring with kitten"

On admission the pain was higher on exercise in the majority of our patients

The surgical procedures performed are summarized in Table 2.

The average pain intensities were 3 to 6 th hour; 2 to $24^{\text {th }}$ hour; 1.6 to $48^{\text {th }}$ hour; and 1.2 to $72^{\text {th }}$ hour.

The type of surgery had an effect on pain at 24 hour with a statistical test $\mathrm{X}^{2}=144.83$

Table 1. The main digestive cancers.

\begin{tabular}{ccc}
\hline Digestive cancers Operated & Number & Percentage \\
\hline Esophagus & 4 & $3.30 \%$ \\
Stomach & 61 & $50.40 \%$ \\
Pancreas & 7 & $5.80 \%$ \\
Liver & 4 & $3.30 \%$ \\
Gallbladder & 2 & $1.60 \%$ \\
Colon & 33 & $27.30 \%$ \\
Rectum & 6 & $4.90 \%$ \\
Small intestine & 4 & $3.30 \%$ \\
Total & 121 & $100 \%$ \\
\hline
\end{tabular}

Table 2. The surgical procedures performed.

$\begin{array}{ccc}\text { Gestures } & \text { Number } & \text { Percentage } \\ \text { Biopsy } & 29 & 24 \% \\ \text { Hepatectomie segmentaire } & 6 & 4.1 \% \\ \text { Derivation Bilio Digestive } & 8 & 6.6 \% \\ \text { Gastro Entero Anastomosis } & 17 & 14 \% \\ \text { Duodeno Pancreatectomy Cephalic } & 4 & 3.3 \% \\ \text { Cholecystectomy } & 2 & 1.6 \% \\ \text { Gastrectomy } 4 / 5 \text { lymphadenectomy } & 6 & 5 \% \\ \text { Resection anastomosis of colon + lymphadenectomy } & 10 & 8.3 \% \\ \text { Anterior resection of rectum + lymphadenectomy } & 4 & 3.3 \% \\ \text { Colostomy } & 121 & 12.4 \% \\ \text { Ileostomy } & 4.3 \%\end{array}$


Table 3. This influence.

\begin{tabular}{ccccccccc}
\hline Type of surgery & \multicolumn{2}{c}{ Low pain } & \multicolumn{2}{c}{ Moderate pain } & \multicolumn{2}{c}{ Intense Pain } & \multicolumn{2}{c}{ Very Intense Pain } \\
\hline & Num & $\%$ & Num & $\%$ & Num & $\%$ & Num & $\%$ \\
\hline Gastrectomy & 5 & $83.30 \%$ & 0 & $33.30 \%$ & 1 & $16.70 \%$ & 0 & $16.60 \%$ \\
GEA & 12 & $70.60 \%$ & 5 & $29.40 \%$ & 0 & $0 \%$ & 0 & $0 \%$ \\
Gastrostomy & 9 & $75 \%$ & 3 & $25 \%$ & 0 & $0 \%$ & 0 & $0 \%$ \\
Biopsy & 22 & $75.90 \%$ & 7 & $24.10 \%$ & 0 & $0 \%$ & 0 & $0 \%$ \\
Cholecystectomy & 2 & $100 \%$ & 0 & $0 \%$ & 0 & $0 \%$ & 0 & $0 \%$ \\
Derivation Bilio Digestive & 1 & $12.50 \%$ & 6 & $75 \%$ & 1 & $12.50 \%$ & 0 & $0 \%$ \\
Duodeno Pancreatectomy & 3 & $75 \%$ & 0 & $0 \%$ & 0 & $0 \%$ & 1 & $25 \%$ \\
Ileostomie & 1 & $25 \%$ & 3 & $75 \%$ & 0 & $0 \%$ & 0 & $0 \%$ \\
Resection of anterior rectum & 3 & $75 \%$ & 0 & $0 \%$ & 0 & $0 \%$ & 1 & $25 \%$ \\
Anastomy resection of colon & 0 & $0 \%$ & 6 & $60 \%$ & 3 & $30 \%$ & 1 & $10 \%$ \\
Hepatectomy & 4 & $66.70 \%$ & 2 & $33.30 \%$ & 0 & $0 \%$ & 0 & $0 \%$ \\
Operation according to Akyama & 3 & $75 \%$ & 0 & $0 \%$ & 0 & $0 \%$ & 1 & $25 \%$ \\
Colostomy & 2 & $13.30 \%$ & 12 & $80 \%$ & 1 & $6.70 \%$ & 0 & $0 \%$ \\
\hline
\end{tabular}

GEA, Gastro Entero Anastomosis.

and $\mathrm{P}<0.05$ at $48 \mathrm{~h}$ with a statistical test $\mathrm{X}^{2}=177.36$ and $\mathrm{P}<0.05$; and at 72 hour with a statistical test $\mathrm{X}^{2}=192.16$ and $\mathrm{P}<0.05$.

This influence is shown in Table 3.

The majority of our patients had a treatment protocol involving nefopam, and paracetamol was $58 \%$. The pain was exacerbated especially during exercise. The maximum doses used in the majority of our patients were paracetamol with $28 \mathrm{~g}$ (DPC), nefopam $480 \mathrm{mg}$ (DPC), and morphine $100 \mathrm{mg} / \mathrm{ml}$ (6th hour, Gastrectomy).

Vomiting and vein burning have been the side effects encountered.

\section{Comments and Discussion}

All the patients had been informed in the preoperative phase of the evaluation and the interest of the management of the pain, the visual analogue scale was the evaluation tool, and the protocol of the management of the pain had been well established.

Difficulties have involved the management of certain patients due to the financial problems lack of health insurance for some patients, the shortage of major analgesics in the pharmacy of the hospital, and fear and false beliefs about opiates.

Age is not a determining factor in painful perception [5], as is sex [6].

The first six (6) hours of the procedure are very painful. The number of patients with low to moderate pain as well as those with severe to very intense pain in our series did not differ significantly from that found in the Italian series.39 A large majority of our patients did not have severe pain Very intense at 24 hours postoperatively. This result was also found in the American and Canadian series [7] with no statically significant difference $\mathrm{P}>0.05$, which, like us, assured the management of pain according to a well-defined protocol. On the other hand, in the Chinese series [8], the proportion of 
patients with severe to very intense pain of $80 \%(71 \%)$ and $36(29 \%)$, respectively, was higher with a statistically significant difference $\mathrm{P}<0.05$. Types of surgery, and multimodal management of postoperative pain in our patients $(\mathrm{P}=0.000004)$.

The mean intensities of postoperative pain in our study do not differ from those reported by the authors Lithuanian [9] and Iranian [6] [10] respectively 1, 4; 0.66 and 2.6 with $\mathrm{P}>0.05$ however at 24 hours postoperatively there is no statistically significant difference between the average intensity of our study and that of the Lithuanian author [9]. Higher than those of Iranian authors [6] [10] with a statistically significant difference $\mathrm{P}<0.05$.

This difference with Iranian authors may be related to the protocol for postoperative pain management.

\section{Conclusion}

Surgery triggers or aggravates pain in cancer patients in the early hours of surgery. This pain should be assessed prior to management. This management requires a lot of effort because multidisciplinary (algologist, psychiatrist, surgeon, anesthetist and reanimator).

\section{References}

[1] Daut, R.L. and Cleeland, C.S. (1982) The Prevalence and Severity of Breast Cancer. Cancer, 50, 1913-1918. https://doi.org/10.1002/1097-0142(19821101)50:9<1913::AID-CNCR2820500944>3.0.CO;2-R

[2] (1990) Treatment of Cancer Pain and Palliative Care Report of a WHO Expert Committee. World Health Organization, Geneva, 804.

[3] National Cancer Control Programs (1995) Policies and Managerial Guidelines. World Health Organization, Geneva.

[4] Mann, C. The Treatment of Chronic Cancer Pain. MID Palliative Care Faculty of Medicine Montpellier-Nîmes 2006-2007.

[5] Pommergaard, H.-C., Klein, M. and Burcharth, J. (2014) Variation in Postoperative NonSteroidal Anti-Inflammatory Analgesic Use after Colorectal Surgery: A Database Analysis. BMC Anesthesiology, 14, 18. https://doi.org/10.1186/1471-2253-14-18

[6] Bameshki, A., Yazdi, A.P. and Sheybani, S. (2015) The Assessment of Addition of Either Intravenous Paracetamol or Diclofenac Suppositories to Patient-Controlled Morphine Analgesia for Postgastrectomy Pain Control University of Medical Sciences, Mashhad, Iran. Anesthesiology and Pain Medicine, 5, 29688.

[7] Bergeron Leduc, D.A. and Marchand Bourgault, S. (2011) Descriptive Study of the Process of Evaluation and Documentation of Postoperative Pain in a University Hospital. Bread RES Manage, 16, 81-86.

[8] Liu, W.R., Zhang, L., Woo, S.M.-L., Tang, A.L. and Xie, S.M. (2013) A Study of Patient Experience and Perception Regarding Postoperative Pain Management in Chinese Hospitals. 7, 1157-1162.

[9] Rimaitis, K., Marchertienè, I. and Pavalkis, D. (2003) Comparison of Two Different Methods of Analgesia. Postoperative Stroke after Colorectal Cancer Surgery University of Medicine Hospital, Lithuania Medicina. 2, 39.

[10] Alimian, M., Pournajafian, A. and Kholdebarin, A. (2014) Analgesic Effects of Paracetamol and Morphine after Elective Laparotomy Surgeries Iran University of Medical Sciences, Anesth Pain Med. 
Submit or recommend next manuscript to SCIRP and we will provide best service for you:

Accepting pre-submission inquiries through Email, Facebook, LinkedIn, Twitter, etc. A wide selection of journals (inclusive of 9 subjects, more than 200 journals) Providing 24-hour high-quality service

User-friendly online submission system

Fair and swift peer-review system

Efficient typesetting and proofreading procedure

Display of the result of downloads and visits, as well as the number of cited articles Maximum dissemination of your research work

Submit your manuscript at: http://papersubmission.scirp.org/

Orcontact ss@scirp.org 